\title{
REMOVAL OF ORGANIC MATTER FROM SURFACE WATER USING COAGULANTS WITH VARIOUS BASICITY
}

\author{
Lidia Dąbrowska' \\ 1 Department of Chemistry, Water and Wastewater Technology, Czestochowa University of Technology, \\ Dąbrowskiego 69, 42-200 Częstochowa, Poland, e-mail: dabrowska@is.pcz.czest.pl
}

Received: 2016.03.16 Accepted: 2016.06.01 Published: 2016.07.01

\begin{abstract}
Humic substances are a natural admixture of surface water and determine the level of organic pollution of water and colour intensity. Application of coagulation process in surface water treatment allows for decrease turbidity and colour of water, as well as organic matter content. In Poland most drinking water treatment plants use aluminium sulphate as a coagulant. Research works on pre-hydrolyzed coagulants, e.g. polyaluminium chlorides (general formula $\mathrm{Al}_{\mathrm{n}}(\mathrm{OH})_{\mathrm{m}} \mathrm{Cl}_{3 \mathrm{n}-\mathrm{m}}$ ) are also carried out. The aim of this study was to evaluate the effectiveness of the coagulation process using polyaluminium chlorides with different basicity, in reducing the level of pollution of surface water with organic substances. Apart from the typical indicators used to evaluate the content of organic compounds, the potential for trihalomethanes formation THM-FP was also determined. The influence of the type of coagulant (low, medium, highly alkaline) on the efficiency of organic compound removal, determined as total organic carbon TOC, oxidisability OXI, absorbance $\mathrm{UV}_{254}$, was stated. Under the conditions of the coagulation ( $\mathrm{pH} 7.2-7.4$, temperature of $19-21^{\circ} \mathrm{C}$ ), the best results were obtained using highly alkaline polyaluminium chlorides PAX-XL19F, PAX-XL1905 and PAX-XL1910S, decrease in TOC and OXI by $43-46 \%$, slightly worse $-40-41 \%$ using low alkaline PAX18. Using the medium alkaline coagulants PAX-XL61 and PAXX-XL69, 30-35\% removal of organic matter was obtained. Despite various effects of dissolved organic carbon removal, depending on the used coagulant, THM-FP in purified water did not differ significantly and ranged from 10.0 to $10.9 \mathrm{mgCHCl}_{3}$ $\mathrm{m}^{-3}$. It was by $37-42 \%$ lower than in surface water.
\end{abstract}

Keywords: coagulation, pre-hydrolyzed aluminium salts, organic matter, water.

\section{INTRODUCTION}

Natural organic matter (NOM) is defined as a complex matrix of organic materials present in all natural water. The hydrophilic fractions of NOM are composed mostly of aliphatic carbon and nitrogenous compounds, as carboxylic acids, carbohydrates and proteins. Hydrophobic NOM primarily consists of humic and fulvic acids (humic substances) [Matilainen et al. 2010]. Particular increase of interest in the composition of humic substances in water is noted since the publication of research regarding the generation of trihalomethanes (THMs) during the chlorination of water. Four derivatives of methane belong to THMs group: chloroform $\mathrm{CHCl}_{3}$, bromoform $\mathrm{CHBr}_{3}$, bromodichloromethane $\mathrm{CHCl}_{2} \mathrm{Br}$, dibromochloromethane $\mathrm{CHClBr}_{2}$. The permissible concentration of the sum of their content in drinking water according to [Regulation 2015] equals $100 \mathrm{mg} \mathrm{m}^{-3}$. Analyses of water collected in different water treatment plants in the world [Abdullah et al. 2003; Kim 2009; Chang et al. 2010; Pardakhti et al. 2011], and also in pool water [Lee et al. 2009], confirm the possibility of THMs presence in water subjected to chlorination. In order to reduce THMs concentration in drinking water, various technological approaches are applied: removal of produced THMs, removal of THMs precursors, use of disinfectants other than chlorine. 
THMs precursors are mainly humic acids, metabolites of aquatic organisms, mono-, di- and tricarboxylic acids, and aromatic carboxylic acids [Dojlido 2002]. For the reduction of organic matter in water, coagulation can be used [ŚwiderskaBróż et al. 2008; Matilainen et al. 2010; Alexander et al. 2012; Jeong et al. 2014].

Efficiency of the coagulation process depends on physico-chemical composition of water, $\mathrm{pH}$ value, type and dosage of coagulants. The most often used aluminium coagulants are aluminium sulphate $\mathrm{Al}_{2}\left(\mathrm{SO}_{4}\right)_{3}$ and aluminium chloride $\mathrm{AlCl}_{3}$. In recent years, the usage of pre-hydrolyzed coagulants is more and more popular, e.g. alkaline polyaluminium chlorides with general formula $\mathrm{Al}_{\mathrm{n}}(\mathrm{OH})_{\mathrm{m}} \mathrm{Cl}_{3 \mathrm{n}-\mathrm{m}}$. In solutions of polyaluminium chlorides, besides monomers $\mathrm{Al}^{3+}, \mathrm{Al}(\mathrm{OH})^{2+}$, $\mathrm{Al}(\mathrm{OH})_{2}^{+}$, which are also present in solutions of non-hydrolyzed aluminum coagulants, presence of many polymerized aluminium hydroxyl complexes with general formula $\mathrm{Al}_{\mathrm{p}}(\mathrm{OH})_{\mathrm{q}}{ }^{(3 \mathrm{p}-\mathrm{q})^{+}}$, e.g. $\mathrm{Al}_{2}(\mathrm{OH})_{2}{ }^{4+}, \mathrm{Al}_{3}(\mathrm{OH})_{4}{ }^{5+}, \mathrm{Al}_{13} \mathrm{O}_{4}(\mathrm{OH})_{24}{ }^{7+}$, was identified [Yan et al. 2008]. Polycationic products of preliminary hydrolysis of aluminium, after addition of polyaluminium chlorides to the treated water, undergo the hydrolysis to $\mathrm{Al}(\mathrm{OH})_{3}$ far more slowly than aluminium present in the solution of aluminium sulphate. This results in the fact that the usage of polyaluminium chlorides is more effective in destabilisation of negatively charged colloids, which cause mainly water colour and turbidity, in comparison with the results obtained with the usage of aluminium sulphate. $\mathrm{Al}_{13} \mathrm{O}_{4}(\mathrm{OH})_{24}{ }^{7+}$ is called polymer $\mathrm{A}_{13}$ and is considered as the most stable and effective in destabilisation of negatively charged colloids especially the colloidal particles which causes high turbidity of water [Lin et al. 2008]. Higher effectiveness of hydrolysed coagulants compared to aluminium sulphate results not only from the presence of $\mathrm{Al}_{13}$ polycations but also from the difference in a structure of the aluminium hydroxides which are generated during hydrolysis of these coagulant agents [Lin et al. 2009; 2014].
During water purification by means of the coagulation process, often over 90 and $80 \%$ reduction is obtained respectively for turbidity and colour [Dąbrowska and Rosińska 2013]. Research on treatment of water with different compositions also confirm the effectiveness of the coagulation in the removal of organic matter [Hussain et al. 2013; Wang et al. 2013].

The aim of this study was to evaluate the effectiveness of the coagulation process using prehydrolyzed salts, polyaluminium chlorides with different basicity, in reducing the level of pollution of surface water with organic substances. Apart from the typical indicators used to evaluate the content of organic compounds (total and dissolved carbon, ultraviolet absorbance at 254 $\mathrm{nm}$ ), the potential for trihalomethanes formation THM-FP was also determined. The THM-FP potential reflects the amount of precursors present in water, capable of generating THMs.

\section{MATERIAL AND METODS}

Surface water from the Poraj dam reservoir was used for the study. This reservoir is located on $764 \mathrm{~km}$ of the Warta river, in the area of Poraj and Koziegłowy municipalities. The area of the reservoir is $497 \mathrm{ha}$, length $-4.9 \mathrm{~km}$, the average depth $-3.9 \mathrm{~m}$. The water was collected in November 2015.

Hydrolyzed salts, polyaluminium chlorides with commercial names PAX18, PAX-XL61, PAX-XL69, PAX-XL19F, PAX-XL1905, and PAX-XL1910S, were used as coagulants, produced by KEMIPOL company in Police (Poland). The characteristics of the coagulants are shown in Table 1.

Basicity of polyaluminium chlorides varied from 41 to $85 \%$. The basicity is determined by the ratio of the number of $\mathrm{OH}^{-}$moles to $\mathrm{Al}^{3+}$ in the coagulant, defined as the coefficient $\mathrm{R}=\left[\mathrm{OH}^{-}\right] /\left[\mathrm{Al}^{3+}\right]$. The relation between the $\mathrm{R}$ value and the basicity of the coagulant is as follow:

Table 1. Characteristics of the coagulants

\begin{tabular}{|l|c|c|c|c|c|c|c|}
\hline \multirow{2}{*}{ Parameter } & \multirow{2}{*}{ Unit } & \multicolumn{5}{|c|}{ PAX } \\
\cline { 3 - 8 } & & 18 & XL61 & XL69 & XL19F & XL1905 & XL1910S \\
\hline Basicity & $\%$ & $41.0 \pm 3$ & $70.0 \pm 10$ & $60.0 \pm 10$ & $85.0 \pm 5$ & $85.0 \pm 5$ & $85.0 \pm 5$ \\
\hline $\mathrm{Al}_{2} \mathrm{O}_{3}$ & $\%$ & $17.0 \pm 0.6$ & $10.2 \pm 0.4$ & $11.3 \pm 0.9$ & $16.0 \pm 0.9$ & $11.3 \pm 0.9$ & $19.8 \pm 0.4$ \\
\hline Chlorides & $\%$ & $21.0 \pm 2.0$ & $11.0 \pm 2.0$ & $11.0 \pm 2.0$ & $5.5 \pm 0.5$ & $5.0 \pm 1.0$ & $7.5 \pm 1.0$ \\
\hline $\mathrm{pH}$ & - & $1.0 \pm 0.2$ & $3.0 \pm 0.5$ & $2.5 \pm 0.5$ & $4.0 \pm 0.5$ & $3.6 \pm 0.4$ & $3.5 \pm 0.5$ \\
\hline
\end{tabular}


basicity $(\%)=\mathrm{R} / 0.03$. Commercial solutions of PAX contained from 10.2 to $19.8 \%$ of $\mathrm{Al}_{2} \mathrm{O}_{3}$. For the analyses, coagulant solutions were prepared by diluting commercial products so that they contained $1.0 \mathrm{gAl} \mathrm{dm}^{-3}$.

In the first stage, the coagulation process was conducted in glass beakers with $2 \mathrm{dm}^{3}$ volume, to each beaker $1.5 \mathrm{dm}^{3}$ of analysed water was measured. The coagulants were introduced in amounts of 2,3 and $4 \mathrm{mgAl} \mathrm{dm}^{-3}$, and with the use of a mechanical stirrer fast stirring was executed for 2 minutes (applying 250 RPM), and then slow stirring for 15 minutes (25 RPM). After this time the samples were subjected to 1 hour sedimentation. Afterwards $0.5 \mathrm{dm}^{3}$ of water was decanted and analysed. The scope of the analysis of water after the coagulation included: $\mathrm{pH}$, turbidity, colour, total organic carbon, oxidisability.

In the second stage, execution of the coagulation process was repeated using a coagulant dose equal to $4 \mathrm{mgAl} \mathrm{dm}^{-3}$. The scope of the analysis of water after the coagulation included: dissolved organic carbon, ultraviolet absorbance at $254 \mathrm{~nm}$, aluminium, trihalomethane formation potential.

The physicochemical parameters of water were measured with the following methods: $\mathrm{pH}$ - potentiometrically; turbidity - nephelometric with Eutech Instruments TN-100 nephelometer; colour - colometrically with platinum-cobalt standard method; dissolved (DOC) and total organic carbon (TOC) - by infrared spectrophotometry with carbon analyser Multi N/C, Analytik Jena (to measure DOC concentration the samples of water were filtered through $0.45 \mu \mathrm{m}$ filtration membrane); oxidisability (OXI) by potassium permanganate method; aluminium - with Aquaquant 14413 aluminium test. Absorbance in the ultraviolet UV at wavelength of $254 \mathrm{~nm}$ was determined (spectrophotometer M501 by Camspec) using $1 \mathrm{~cm}$ quartz cells. SUVA ${ }_{254}$ index was calculated as the ratio of absorbance at $\mathrm{UV}_{254}$ to the DOC content. Connecting the values of absorbance and DOC into single coefficient SUVA $_{254}$ enables to determine properties of dissolved organic matter in water, and vulnerability to their removal in the coagulation process.

In order to determine the THM-FP, measured into dark bottles surface water samples before treatment and after the coagulation, adjusted to pH 7 with phosphate buffer, were chlorinated using chlorine water prepared with sodium hypochlorite. Such dose was used to achieve, after a period of 24 hours at the temperature of $25^{\circ} \mathrm{C}$, a concentration of residual free chlorine in the range of 3 to $4 \mathrm{mgCl}_{2} \mathrm{dm}^{-3}$ [APHA 1998]. The concentration of chlorine in the chlorine water was determined iodometrically, and the chlorine remaining after 24 hours in water samples by means of spectrophotometric method using orthotolidine as a factor in the colour reaction. For the determination of THMs in water samples before and after the chlorination process, $10 \mathrm{~cm}^{3}$ of water was collected into tubes, $1 \mathrm{~cm}^{3}$ of n-pentane was added, and it was intensively shaken for 1 minute. After separation of the layers, $2 \mathrm{~mm}^{3}$ of the extract was collected with a microsyringe and introduced into a chromatography column. Nitrogen was used as a carrier gas. Distribution of the compounds was performed on a capillary column DB-5 $(30 \mathrm{~m} \times 0.25 \mathrm{~mm} \times 0.25 \mu \mathrm{m})$ and analyzed by means of gas chromatography with microelectron capture detector $\mu \mathrm{ECD}$ (chromatograph Agilent $6890 \mathrm{~N}$ ). Temperature program: starting at $40^{\circ} \mathrm{C}$, ramp $40^{\circ} \mathrm{C} / \mathrm{min}$ to $120^{\circ} \mathrm{C}$, then $15^{\circ} \mathrm{C} / \mathrm{min}$ to $250^{\circ} \mathrm{C}$. As a standard, solution by CPAchem Ltd was used, containing 4 components $\left(\mathrm{CHCl}_{3}\right.$, $\mathrm{CHBr}_{3}, \mathrm{CHCl}_{2} \mathrm{Br}, \mathrm{CHClBr}_{2}$ ) with a concentration of $10 \mu \mathrm{g} \mathrm{cm}^{-3}$ each in iso-octane.

The potential for trihalomethane formation was calculated by subtracting the initial THMs concentration from the concentration of these compounds determined after 24 hour contact of water with chlorine.

\section{RESULTS AND DISCUSSION}

Surface water was characterized by colour equal to $25 \mathrm{gPt} \mathrm{m}^{-3}$ and turbidity of $7.6 \mathrm{NTU}$. The TOC and the DOC content amounted to 8.8 and $7.4 \mathrm{gC} \mathrm{m}^{-3}$ respectively, and the absorbance at $\mathrm{UV}_{254}-17.6 \mathrm{~m}^{-1}$. Thus the $\mathrm{SUVA}_{254}$ value was equal to $2.38 \mathrm{~m}^{2}(\mathrm{gC})^{-1}$. The $\mathrm{SUVA}_{254}$ value in the range of $2-4 \mathrm{~m}^{2}(\mathrm{gC})^{-1}$ suggests that in the surface water occurred a mixture of hydrophilic and hydrophobic humic substances and other natural organic compounds, both of low and high molecular weights. At the same time, as the literature states [Mołczan et al. 2006], in case of waters with a value of this index $<3 \mathrm{~m}^{2}(\mathrm{gC})^{-1}$, the degree of DOC removal generally does not exceed $30 \%$.

The effectiveness of turbidity and colour removal by various coagulants are presented in Table 2, as well as changes in OXI and TOC concentration during coagulation. Based on the results of turbidity removal efficiency it was stated that the 
Table 2. Effect of coagulation with various agents on selected physicochemical properties of water

\begin{tabular}{|c|c|c|c|c|c|c|}
\hline Coagulant & $\begin{array}{c}\text { Dose } \\
{\left[\mathrm{gAl} \mathrm{m}^{-3}\right]}\end{array}$ & $\begin{array}{c}\mathrm{pH} \\
- \\
\end{array}$ & $\begin{array}{c}\text { Turbidity } \\
\text { [NTU] }\end{array}$ & $\begin{array}{c}\text { Colour } \\
{\left[\mathrm{gPt} \mathrm{m}^{-3}\right]}\end{array}$ & $\begin{array}{c}\mathrm{PV} \\
{\left[\mathrm{gO}_{2} \mathrm{~m}^{-3}\right]}\end{array}$ & $\begin{array}{c}\mathrm{TOC} \\
{\left[\mathrm{gC} \mathrm{m}^{-3}\right]}\end{array}$ \\
\hline Raw water & - & 7.42 & 7.6 & 25.0 & 5.4 & 8.8 \\
\hline \multirow{3}{*}{ PAX18 } & 2 & 7.36 & 2.9 & 15.0 & 3.9 & 6.1 \\
\hline & 3 & 7.28 & 1.4 & 10.0 & 3.4 & 5.7 \\
\hline & 4 & 7.22 & 0.9 & 5.0 & 3.2 & 5.3 \\
\hline \multirow{3}{*}{ PAX-XL61 } & 2 & 7.38 & 3.5 & 15.0 & 3.9 & 6.2 \\
\hline & 3 & 7.31 & 2.6 & 10.0 & 3.8 & 5.9 \\
\hline & 4 & 7.26 & 1.8 & 7.5 & 3.5 & 5.7 \\
\hline \multirow{3}{*}{ PAX-XL69 } & 2 & 7.37 & 3.3 & 20.0 & 4.4 & 6.5 \\
\hline & 3 & 7.30 & 2.2 & 15.0 & 4.2 & 6.4 \\
\hline & 4 & 7.24 & 1.5 & 10.0 & 3.8 & 6.1 \\
\hline \multirow{3}{*}{ PAX-XL19F } & 2 & 7.40 & 2.4 & 10.0 & 3.4 & 5.5 \\
\hline & 3 & 7.38 & 1.5 & 7.5 & 3.1 & 5.1 \\
\hline & 4 & 7.34 & 0.9 & 7.5 & 3.0 & 4.8 \\
\hline \multirow{3}{*}{ PAX-XL1905 } & 2 & 7.39 & 2.2 & 10.0 & 3.4 & 5.6 \\
\hline & 3 & 7.33 & 1.6 & 5.0 & 3.2 & 5.4 \\
\hline & 4 & 7.31 & 0.9 & 5.0 & 2.9 & 4.9 \\
\hline \multirow{3}{*}{ PAX-XL1910S } & 2 & 7.40 & 2.1 & 12.5 & 3.6 & 5.6 \\
\hline & 3 & 7.36 & 1.3 & 7.5 & 3.2 & 5.2 \\
\hline & 4 & 7.32 & 0.8 & 5.0 & 3.1 & 4.9 \\
\hline
\end{tabular}

most effective agent (under the conditions of coagulation process: $\mathrm{T}=19-21^{\circ} \mathrm{C}, \mathrm{pH} 7.2-7.4$ ) was PAX-XL1910S. Application of this product at dose of $4 \mathrm{mgAl} \mathrm{dm}^{-3}$ decreased turbidity of water from 7.6 to 0.8 NTU. Also PAX18, PAX-XL19F, PAX-XL1905 agents were effective in removing of turbidity (decreased turbidity to 0.9 NTU).

PAX18, PAX-XL1905, PAX-XL1910S were also the most effective products for colour removal (decreased colour from 25 to $5 \mathrm{gPt} \mathrm{m}^{-3}$ ). PAXXL61 and PAX-XL19F agents reduced colour to $7.5 \mathrm{~g} \mathrm{Pt} \mathrm{m}^{-3}$, whereas PAX-XL69 to $10 \mathrm{gPt} \mathrm{m}^{-3}$.

The efficiency of removal of organic compounds depended both on the type of the coagulant, and on its dose. The best results were obtained with a dose of coagulants equal to $4 \mathrm{mgAl}$ $\mathrm{dm}^{-3}$. The content of organic compounds after the coagulation process carried out using low-alkaline PAX18, determined as OXI and TOC, decreased respectively from $5.4 \mathrm{gO}_{2} \mathrm{~m}^{-3}$ and $8.8 \mathrm{gC}$ $\mathrm{m}^{-3}$ to $3.2 \mathrm{gO}_{2} \mathrm{~m}^{-3}$ and $5.3 \mathrm{gC} \mathrm{m}^{-3}$. The absorbance value $\mathrm{UV}_{254}$ decreased by $8.4 \mathrm{~m}^{-1}$. With the usage of medium alkaline polyaluminium chlorides PAX-XL61 and PAX-XL69, a reduction in TOC content was obtained, respectively to 5.7 and $6.1 \mathrm{gC} \mathrm{m}^{-3}$, and the OXI to 3.5 and $3.8 \mathrm{gO}_{2} \mathrm{~m}^{-3}$. The best results of organic compound content reduction were obtained with the usage of highly alkaline coagulants: PAX-XL1905, PAX-XL19F, and PAX-XL1910S. The TOC content in water after the coagulation was equal to $4.8-4.9 \mathrm{gC} \mathrm{m}^{-3}$, and the OXI $-2.9-3.1 \mathrm{gO}_{2} \mathrm{~m}^{-3}$. A higher basicity of the coagulant usually indicates its higher efficiency, resulting from a greater portion of polymerized forms. This is confirmed by various laboratory tests [Rak and Świderska-Bróż 2003; Yang et al. 2011a; Yang et al. 2011b; Dąbrowska and Rosińska 2013]. However, the experience gained in water treatment plants have shown that even under the same operating conditions of the coagulation ( $\mathrm{pH}$, coagulant dose), the outcome of this process does not always confirm this relation [Gumińska 2012]. Therefore, in each case, it is necessary to choose an appropriate coagulant, its dosage and the process parameters.

Lowering the DOC content in water after the coagulation was in the range of $22-39 \%$, and the $\mathrm{UV}_{254}$ absorbance in the range of $48-59 \%$, depending on the used coagulant - Table 3. The largest reduction in values of those indicators were stated using highly alkaline hydrolyzed chlorides PAX-XL19F and PAX-XL1910S. It is believed [Mołczan et al. 2006], that significant reduction in the value of the absorbance during the coagulation is obtained by removing the hydrophobic and remaining the hydrophilic fraction of the DOC. 
Table 3. Effect of coagulation with various agents on selected physicochemical properties of water

\begin{tabular}{|l|c|c|c|c|c|c|}
\hline \multicolumn{1}{|c|}{ Coagulant } & $\begin{array}{c}\text { Dose } \\
{\left[\mathrm{gAl} \mathrm{m}{ }^{-3}\right]}\end{array}$ & $\begin{array}{c}\mathrm{pH} \\
-\end{array}$ & $\begin{array}{c}\mathrm{Al} \\
{\left[\mathrm{gAl} \mathrm{m}^{-3}\right]}\end{array}$ & $\begin{array}{c}\mathrm{DOC} \\
{\left[\mathrm{gC} \mathrm{m}^{-3}\right]}\end{array}$ & $\begin{array}{c}\mathrm{UV}_{254} \\
{\left[\mathrm{~m}^{-1}\right]}\end{array}$ & $\begin{array}{c}\text { SUVA } \\
{\left[\mathrm{m}^{2}(\mathrm{gC})^{-1}\right]}\end{array}$ \\
\hline Raw water & - & 7.42 & $<0.05$ & 7.4 & 17.6 & 2.38 \\
\hline PAX18 & 4 & 7.22 & 0.18 & 5.1 & 8.4 & 1.65 \\
\hline PAX-XL61 & 4 & 7.26 & 0.25 & 5.5 & 8.8 & 1.60 \\
\hline PAX-XL69 & 4 & 7.24 & 0.30 & 5.8 & 9.2 & 1.59 \\
\hline PAX-XL19F & 4 & 7.34 & 0.10 & 4.5 & 7.3 & 1.62 \\
\hline PAX-XL1905 & 4 & 7.31 & 0.05 & 4.8 & 7.8 & 1.63 \\
\hline PAX-XL1910S & 4 & 7.32 & 0.07 & 4.7 & 7.5 & 1.60 \\
\hline
\end{tabular}

The SUVA value was equal to $1.56-1.65$. This confirms that in water after the coagulation, organic substances remained, which are unsusceptible to the removal in this process. As research has shown [Szlachta and Adamski 2008], the coagulation is the most effective in the removal of compounds with molecular weight of $2.2-5.3 \mathrm{kDa}$, whose content in water was reduced by about $62 \%$. Whereas for organic substances with lower molecular weights $1.5-2.2 \mathrm{kDa}$ and $1.0-1.6 \mathrm{kDa}$ amounted to 25 and $11 \%$, respectively.

The effect of alkalinity of aluminium coagulants and water $\mathrm{pH}$ on the removal of organic substances was also studied by Świderska-Bróż et al. [2008]. The authors stated that with increasing dose and alkalinity of coagulants and decreasing water $\mathrm{pH}$, the coagulants efficiency in removal of analyzed fractions of organic substances increased. DOC share in TOC had also a significant meaning. With increasing participation of DOC in TOC, efficiency of organic compounds removal decreased.

The lowest concentration of remaining aluminium occurred in water after the coagulation, when highly alkaline PAX were applied. It ranged from 0.05 to $0.10 \mathrm{gAl} \mathrm{m}^{-3}$ and it was lower than the permissible value for drinking water of
$0.2 \mathrm{gAl} \mathrm{m}^{-3}$ [Regulation 2015]. Also, using low alkaline PAX18, residual aluminium concentration of less than $0.2 \mathrm{gAl} \mathrm{m}^{-3}$ was obtained, while using medium alkaline PAX-XL61 and PAXXL69 - it was higher than this value.

In the collected surface water, as well as in the water after the coagulation process, presence of trihalomethanes was not observed. However, their presence was demonstrated in these waters after the chlorination process. THM concentration in surface water and in water purified in the coagulation process, after 24 hour period of contact with chlorine, are shown in Table 4. Trihalomethane formation potential THM-FP is given in conversion to $\mathrm{mgCHCl}_{3} \mathrm{~m}^{-3}$.

In the surface water subjected to chlorination, presence of $\mathrm{CHCl}_{3}$ and $\mathrm{CHCl}_{2} \mathrm{Br}$ was demonstrated, $\mathrm{CHBr}_{3}$ and $\mathrm{CHClBr}_{2}$ were not detected. $\mathrm{CHCl}_{3}$ and $\mathrm{CHCl}_{2} \mathrm{Br}$ concentration was equal to 15.36 and $2.64 \mathrm{mg} \mathrm{m}^{-3}$, respectively. In the water subjected to chlorination after the coagulation process, $\mathrm{CHCl}_{3}$ concentration ranged from 8.52 to $9.45 \mathrm{mg} \mathrm{m}^{-3}$, while $\mathrm{CHCl}_{2} \mathrm{Br}$ from 1.92 to $2.16 \mathrm{mg} \mathrm{m}^{-3}$. The lowest concentration of these compounds were obtained in the water subjected to chlorination after previous treatment using PAX-XL19F and PAX-XL1910S.

Table 4. THM concentration in surface water and in water purified in the coagulation process

\begin{tabular}{|c|c|c|c|c|c|}
\hline \multirow{2}{*}{ Coagulant } & \multicolumn{4}{|c|}{ THM [mg m-3] } & \multirow{2}{*}{$\begin{array}{c}\text { THM-FP } \\
{\left[\mathrm{mg} \mathrm{m}^{-3} \text { as } \mathrm{CHCl}_{3}\right]}\end{array}$} \\
\hline & $\mathrm{CHCl}_{3}$ & $\mathrm{CHCl}_{2} \mathrm{Br}$ & $\mathrm{CHClBr}_{2}$ & $\mathrm{CHBr}_{3}$ & \\
\hline Raw water & 15.36 & 2.64 & nd & nd & 17.28 \\
\hline PAX18 & 8.76 & 2.08 & nd & nd & 10.28 \\
\hline PAX-XL61 & 9.12 & 2.16 & nd & nd & 10.69 \\
\hline PAX-XL69 & 9.48 & 2.10 & nd & nd & 10.94 \\
\hline PAX-XL19F & 8.61 & 1.92 & nd & nd & 10.01 \\
\hline PAX-XL1905 & 8.88 & 2.04 & nd & nd & 10.37 \\
\hline PAX-XL1910S & 8.52 & 2.10 & nd & nd & 10.05 \\
\hline
\end{tabular}

nd - not detected 
Despite various effects of dissolved organic carbon removal, depending on the used coagulant, THM formation potential in purified water did not differ significantly and ranged from 10.0 to $10.9 \mathrm{mgCHCl}_{3} \mathrm{~m}^{-3}$. It was by $37-42 \%$ lower than in surface water. Although during the coagulation process a significant portion of organic matter was removed, yet the remaining part was still characterized by a high THM formation potential. The content of organic carbon is, however, only one of the conditions determining the formation of THMs. Other factors influencing the mechanism of THM formation are mainly the $\mathrm{pH}$, time, temperature and the presence of bromides [Abdullah et al. 2003; Hong et al. 2007; Platikanov et al. 2012].

\section{CONCLUSIONS}

The influence of the type of coagulant (low, medium, highly alkaline) on the efficiency of organic compound removal, determined as total organic carbon TOC, oxidisability OXI, ultraviolet absorbance at $254 \mathrm{~nm}$ was stated. Under the conditions of the coagulation ( $\mathrm{pH} 7.2-7.4$, temperature of $19-21^{\circ} \mathrm{C}$ ), the best results were obtained using highly alkaline polyaluminium chlorides PAX-XL19F, PAX-XL1905 and PAX-XL1910S, decrease in TOC and OXI by $43-46 \%$, slightly worse $-40-41 \%$ using low alkaline PAX18. Using the medium alkaline coagulants PAX-XL61 and PAX-XL69, 30$35 \%$ removal of organic matter was obtained. Considering the concentration of aluminium remaining after the coagulation process performed in these conditions, applying highly alkaline coagulants was most advantageous. Despite various effects of dissolved organic carbon removal, depending on the coagulant used, THM formation potential in purified water did not differ significantly and ranged from 10.0 to $10.9 \mathrm{mgCHCl}_{3} \mathrm{~m}^{-3}$. It was by $37-42 \%$ lower than in surface water.

\section{Acknowledgements}

This research was supported by Czestochowa University of Technology, project BS-PB-402-301/11.

\section{REFERENCES}

1. Abdullah Md.P., Yew C.H., Salleh bin Ramli M. 2003. Formation, modeling and validation of trihalomethanes (THM) in Malaysian drinking water: a case study in the districts of Tampin, Negeri Sembilan and Sabak Bernam, Selangor, Malaysia. Water Research, 37, 4637-4644.

2. APHA 1998. Standard methods for the examination of water and wastewater. 20th ed. American Public Health Association, Washington, DC.

3. Alexander J.T., Hai F.I., Al-aboud T.M. 2012. Chemical coagulation-based processes for trace organic contaminant removal: Current state and future potential. Journal of Environmental Management, 111, 195-207.

4. Chang H.H, Tung H.H., Chao C.C., Wang G.S. 2010. Occurrence of haloacetic acids (HAAs) and trihalomethanes (THMs) in drinking water of Taiwan. Environmental Monitoring and Assessment 162, 237-250.

5. Dąbrowska L., Rosińska A. 2013. Removal of PCBs and heavy metal ions from surface water by coagulation. Rocznik Ochrona Środowiska, 15, 1228-1242.

6. Dojlido J. (red) 2002. Uboczne produkty dezynfekcji wody. Seria Wodociągi i Kanalizacja nr 9. Wyd. ZG PZIiTŚ, Warszawa.

7. Gumińska J. 2012. Analysis of the possibility to assess the prehydrolyzed coagulants based on their basicity. Przemysł Chemiczny, 91 (12), 2351-2354.

8. Hong H.C., Liang Y., Han B.P, Mazumder A., Wong M.H. 2007. Modeling of trihalomethane (THM) formation via chlorination of the water from Dongjiang River (source water for Hong Kong's drinking water). Science of the Total Environment, 385, 48-54.

9. Hussain S., van Leeuwen J., Chow Ch., Beecham S., Kamruzzaman M., Wang D., Drikas M., Aryal R. 2013. Removal of organic contaminants from river and reservoir waters by three different aluminum-based metal salts: Coagulation adsorption and kinetics studies. Chemical Engineering Journal, 225, 394-405.

10. Jeong S., Sathasivan A., Kastl G., Shim W.G., Vigneswaran S. 2014. Experimental investigation and modeling of dissolved organic carbon removal by coagulation from seawater. Chemosphere, 95, 310-316.

11. Kim J. 2009. Fate of THMs and HAAs in low TOC surface water. Environmental Research, 109, 158-165.

12. Lee J., Ha K-T., Zoh K-D. 2009. Characteristics of trihalomethane (THM) production and associated health risk assessment in swimming pool waters treated with different disinfection methods. Science of the Total Environment, 407, 1990-1997. 
13. Lin Jr-L., Huang Ch., Pan J.R., Wang D. 2008. Effect of Al(III) speciation on coagulation of highly turbid water. Chemosphere, 72, 189-196.

14. Lin Jr_L., Ch. Huang, Chin Ch-J., Pan J.R. 2009. The origin of $\mathrm{Al}(\mathrm{OH})_{3}$-rich and $\mathrm{Al}_{13}$-aggregate flocs composition in $\mathrm{PACl}$ coagulation. Water Research, 43, 4285-4295.

15. Lin Jr-L, Huang Ch., Dempsey B., Hu J-Y. 2014. Fate of hydrolyzed Al species in humic acid coagulation. Water Research, 56, 314-324.

16. Matilainen A., Vepsäläinen M., Sillanpää M. 2010. Natural organic matter removal by coagulation during water treatment: A review. Advances in Colloid and Interface Science, 159, 189v197.

17. Mołczan M., Szlachta M., Karpińska A., Biłyk A. 2006. Water quality assessment in term sof specific UV absorbance. Ochrona Środowiska 28 (4), 11-16.

18. Pardakhti A.R., Bidhendi G.R.N., Torabian A., Karbassi A., Yunesian M. 2011. Comparative cancer risk assessment of THMs in drinking water from well water sources and surface water sources. Environmental Monitoring and Assessment, 179, 499-507.

19. Platikanov S., Martín J., Tauler R. 2012. Linear and non-linear chemometric modeling of THM formation in Barcelona's water treatment plant. Science of the Total Environment, 432, 365-374.

20. Rak M., Świderska-Bróż M. 2003. On the usefulness of prehydrolysed coagulant to organic matter removal from water. Inżynieria i Ochrona Środowiska, 6 (3-4), 347-359.

21. Regulation 2015. Regulation of the Minister of Health from 13 November 2015 on the qual- ity of water intended for human consumption (Rozporządzenie Ministra Zdrowia z dnia 13 listopada 2015 roku w sprawie jakości wody przeznaczonej do spożycia przez ludzi. Poz. 1989).

22. Świderska-Bróż M., Rak M., Mołczan M., Biłyk A. 2008. Effect of the basicity of aluminium coagulants and the $\mathrm{pH}$ of the water on the removal of organic pollutants. Ochrona Środowiska, 30 (4), 29-33.

23. Szlachta M., Adamski W. 2008. Assessing the efficiency of natural organic matter (NOM) removal from water by coagulation. Ochrona Środowiska, 30 (3), 9-13.

24. Wang D., Zhao Y., Xie J., Chow Ch.W.K., van Leeuwen J. 2013. Characterizing DOM and removal by enhanced coagulation: A survey with typical Chinese source waters. Separation and $\mathrm{Pu}-$ rification Technology, 110, 188-195.

25. Yan M., Wang, D. Ni J., Qu J., Chow Ch.W.K., Liu H. 2008. Mechanism of natural organic matter removal by polyaluminum chloride: Effect of coagulant particle size and hydrolysis kinetics. Water Research, 42, 3361-3370.

26. Yang Z., Gao B., Wang Y., Wang Q., Yue Q. 2011a. Aluminum fractions in surface water from reservoirs by coagulation treatment with polyaluminum chloride (PAC): Influence of initial $\mathrm{pH}$ and $\mathrm{OH}^{-} / \mathrm{Al}^{3+}$ ratio. Chemical Engineering Journal, 170, 107-113.

27. Yang Z., Gao B., Cao B., Xu W., Yue Q. 2011b. Effect of $\mathrm{OH}^{-} / \mathrm{Al}^{3+}$ ratio on the coagulation behavior and residual aluminum speciation of polyaluminum chloride (PAC) in surface water treatment. Separation and Purification Technology, 80, 59-66. 